\title{
Hurricanes and the Urban Forest: I. Effects on Southeastern United States Coastal Plain Tree Species
}

\author{
Mary L. Duryea, Eliana Kampf, and Ramon C. Littell
}

\begin{abstract}
Several hurricanes struck Florida, U.S. in 2004 and 2005 causing widespread damage to urban and rural areas. We measured the impacts of five of these hurricanes on the urban forest and combined these results with four other hurricanes to present an assessment of wind resistance for southeastern United States coastal plain tree species. Urban forest loss was positively correlated with wind speed. Tree species demonstrating the highest survival in winds were sand live oak (Quercus geminata), American holly (Ilex opaca), southern magnolia (Magnolia grandiflora), live oak (Quercus virginiana), wax myrtle (Myrica cerifera), sweetgum (Liquidambar styraciflua), crapemyrtle (Lagerstroemia indica), dogwood (Cornus florida), and sabal palm (Sabal palmetto). In a statistical comparison of sand live oak, live oak, and laurel oak (Quercus laurifolia) survival after four panhandle hurricanes, laurel oak had significantly poorer survival than both live oak and sand live oak. Among all species, larger trees lost more branches than medium and smaller trees. Leaf loss had a positive relationship with survival; losing leaves during the hurricane meant higher survival. Trees growing in groups or clusters had greater survival than those growing as individual trees. Tree species with higher wood density had greater survival. Tree species categorized as having dense crowns lost more branches than those with moderate and open crowns; however, contrary to the literature, dense-crowned species survived best. A survey of arborists, scientists, and urban foresters ranked species for their wind resistance. Using our results from hurricane measurements and incorporating results from the survey and the scientific literature, we have developed lists of relative wind resistance for tree species in the southeastern coastal plain. These lists should be used with caution with the knowledge that no species and no tree is completely windproof. In addition, local considerations such as soil, cultural practices, tree age and health, and other urban forest conditions need to be taken into account.
\end{abstract}

Key Words. Trees; tropical storms; urban trees; wind.

In 2004, four hurricanes struck Florida with maximum sustained winds ranging from 169 to $233 \mathrm{~km} / \mathrm{h}$ (105 to $145 \mathrm{mph}$ ). In 2005, Hurricane Dennis struck the Florida panhandle at $193 \mathrm{~km} / \mathrm{h}$ (120 mph). The impacts of these five hurricanes were widespread ranging from urban areas to agricultural croplands to Florida's natural ecosystems. Since 1992 when Hurricane Andrew struck south Florida, we have been studying the impacts of hurricanes on the urban forest (Duryea et al. 1996). We continued with measurements of hurricane wind damage to urban neighborhoods again in 1995 when two hurricanes struck the Pensacola, Florida, area (Duryea 1997) and then again in 1998 when Hurricane Georges crossed over the entire island of Puerto Rico. These nine hurricanes with their varied wind speeds gave us the opportunity to study over 80 tree species and their comparable responses to hurricanes. This study reports on and synthesizes the types of tree damage, possible reasons for damage, and ways to avert damage in the future for southeastern coastal plain species in urban forests. Tropical and subtropical species are reported in a separate article in this issue.

A considerable number of studies have investigated the effects of hurricane force winds on damage, mortality, and recovery of tree populations within natural forest ecosystems. In general, they have found that large trees (with large diameters and heights) experience more wind damage (Glitzenstein and Harcombe 1988; Webb 1989; Walker 1991) and older forests are more damaged (Everham and Brokaw 1996). Several studies report that tree species respond differently with uprooting, stem breakage, or crown damage (Gresham et al. 1991; reviewed in Everham and Brokaw 1996). Everham and Brokaw rate 242 tree species from 47 studies for wind resistance in low- and high-intensity storms. When species are categorized according to conifers and dicots or by successional class (pioneer versus nonpioneer species), no clear trends are apparent. This lack of correlation with damage is also true for the influence of topography where damage ap- 
pears to be predictable on a large scale (for example, the windward versus leeward sides of a mountain) but inconsistent at smaller topographic scales (Everham and Brokaw 1996).

When trying to explain differences in damage, many studies have found greater damage with increasing hurricane intensity (Tanner et al. 1991). Increased rainfall associated with a hurricane and saturated soils results in more tree mortality and especially the uprooting of trees (Cremer et al. 1982; Peterson and Pickett 1991; Tanner et al. 1991). Several studies have found a negative correlation between wood density and mortality during hurricanes (Putz et al. 1983; Webb 1989; Zimmerman et al. 1994). The size, shape, and openness of the crown may also be related to the extent of damage (Curtis 1943). Foster (1988) found that full crowns were more susceptible to wind compared with trees with a more tapered shape. Dense-crowned trees have been found to be more easily damaged compared with open-foliage crowns (Curtis 1943; Everham and Brokaw 1996). This corresponds to our Hurricane Andrew results in which pruned trees (with more open and well-distributed crowns) were more windresistant than unpruned trees (Duryea et al. 1996). On a stand level, Everham and Brokaw (1996) report that thinned forests (especially recently thinned) are more vulnerable to high winds because of increased wind flow in the canopy and the absence of neighboring trees. Barry et al. (1993) summarize wind resistance as being dependent on tree species and then on five factors: wood strength, crown shape and size, extent and depth of the root system, soil moisture conditions, and shape of the stem.

Studies of urban tree response to hurricanes are not as common yet have yielded interesting and useful results. After Hurricane Hugo struck Puerto Rico in 1989, Francis and Gillespie (1993) found that trees were more damaged with increasing wind gust speed and increasing diameter. Palms were significantly more resistant to wind than broad-leaved trees. After Hurricane Georges in Puerto Rico, Francis (2000) found a correlation between tree size and defoliation and crown loss. He also found differences in extent and type of damage for 24 species in the University of Puerto Rico Botanical Garden. Trees with denser wood and greater branch flexibility were less likely to snap or uproot (Francis 2000). A windstorm that struck Guangzhou City in subtropical south China in 1995 with winds up to $80 \mathrm{~km} / \mathrm{h}(50 \mathrm{mph})$ damaged over 1\% of the tree canopy (Jim and Liu 1997). Tree species differed in their susceptibility to the storm damage; vulnerable species tended to have lower wood density and wide crowns with dense foliage. Shallow root systems also predisposed trees to uprooting in the winds (Jim and Liu 1997). Hurricane Andrew with its $265 \mathrm{~km} / \mathrm{h}(165 \mathrm{mph})$ winds took $38 \%$ of the urban trees in the Miami-Dade County area. In addition to species differences in wind resistance, native trees survived better than exotics (Duryea et al. 1996). Tree prun- ing, an important cultural practice, improved wind resistance of three common species (live oak [Quercus virginiana], black olive [Bucida buceras] and gumbo limbo [Bursera simarouba]). Observations from Hurricanes Camille (1969), Frederick (1979), and Hugo (1989) have resulted in the development of species lists based on flood tolerance, breakage, uprooting, salt, and deterioration by insects and disease (Touliatos and Roth 1971; Swain 1979; Barry et al. 1993).

The objectives of this study were to analyze the effects of hurricane force winds on tree species growing in urban areas in the southeastern United States coastal plain: (1) to determine if there was species-specific damage over the varied wind speeds, and (2) to determine if damage was related to tree attributes (such as size, leaf loss, wood density, and crown shape) and site characteristics (trees growing in groups).

\section{METHODS}

\section{Urban Tree Damage Measurements}

Urban tree damage was measured after (within 3 to 6 days) each hurricane that struck the Florida panhandle (Erin, Opal, Ivan, and Dennis) (Figure 1). We also report the hurricane response of coastal plain species such as live oak and sabal palm (Sabal palmetto) that occur throughout Florida and were impacted by Hurricanes Andrew, Charley, Frances, and Jeanne. Hurricane Andrew results were collected in a survey of 128 homeowners in Dade County, Florida, who reported the impacts of the hurricane on trees in their yards (Duryea et al. 1996). The methodology for the other eight hurricanes was the same and is as follows. Neighborhoods at the point of landfall of the hurricane were randomly chosen on the strong

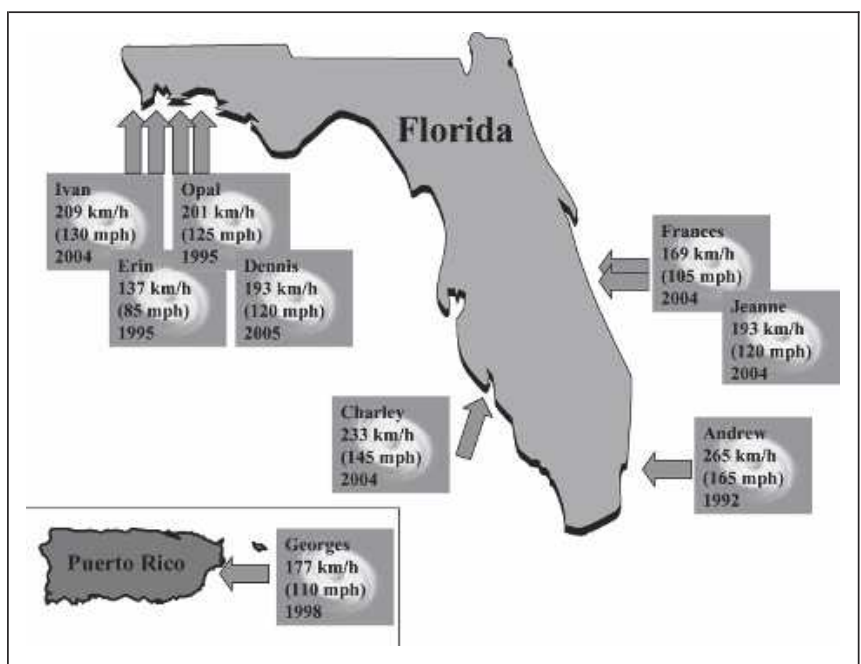

Figure 1. Urban trees were measured after the eight hurricanes striking Florida and one hurricane in Puerto Rico. For each hurricane, the arrow points to the location of landfall. The maximum sustained wind speed $(\mathrm{km} / \mathrm{h}$ and $\mathrm{mph}$ ) and year are included. 
side of the storm. For each neighborhood, all trees in front yards were observed along street transects. (If invited, we also measured trees in backyards.) Overall, we sampled 100 neighborhoods and 18,200 trees. (Branch loss measurements for Hurricanes Frances and Jeanne were combined and collected immediately after Hurricane Jeanne.)

Each tree's diameter at breast height (for dicots and conifers) or height (for palms) was measured (estimated for height) and then it was determined if the tree was standing, leaning, or had fallen. Leaning trees were those that were leaning as a result of the storm at less than a $45^{\circ}$ angle. Fallen trees were either broken at the main stem or lying on the ground. All fallen trees were assessed as either broken or uprooted. Percent survival was calculated for each species using trees that were standing after the hurricane (Trees were considered not surviving if they had fallen or if they were leaning at less than a $45^{\circ}$ angle.).

Crowns of all standing trees were first assessed for percent branch loss and then for leaf loss from the hurricane. For palms, only percent leaf loss was assessed. Then for dicots and conifers, if a tree had $50 \%$ or greater branch loss from the hurricane, it was declared dead and a new second survival percentage was calculated. This is called the "recalculated survival" throughout this article.

For each tree, we also estimated whether it had caused damage to property either from a falling branch or the entire tree. If it had damaged something, we recorded the type of property (for example, fence, power line, or house).

To investigate the reasons why some trees are more windresistant than others, we looked at cluster plantings, wood density, defoliation, and tree crown attributes. To analyze cluster plantings, we assessed whether each tree was growing in a group with other trees or by itself. We defined a cluster as a group of five or more trees growing within $3 \mathrm{~m}(9.9 \mathrm{ft})$ of each other (but not in a row). To investigate the relationship between wind damage and wood characteristics, we obtained wood density, modulus of rupture, and modulus of elasticity for each of the tree species (Reyes et al. 1992; Forest Products Laboratory 1999).

To relate crown characteristics to wind damage, we obtained information on crown density and growth form (excurrent versus decurrent) for each species. Crown density is an estimate of the openness of the crown or the ratio of positive and negative space within the crown (Hightshoe 1988; Gilman 2005). The growth form of a tree can be categorized as excurrent or decurrent. Excurrent trees have strong apical dominance with the main trunk present throughout the life of the tree (giving rise to cone-shaped crowns with a central trunk). Decurrent trees have lateral branches that grow as rapidly as the central trunk; they have no dominant main leader (Harris et al. 2004). We determined from the literature and observation the density class and growth form for each species and then compared open with moderate with dense crowns for branch loss and survival (Hightshoe 1988; Harris et al. 2004; Gilman 2005).

Maximum sustained wind speeds for each hurricane were obtained from the National Oceanic and Atmospheric Administration National Hurricane Center web site (www.nhc. noaa.gov).

\section{The Survey}

After four hurricanes struck Florida in 2004, we concluded that urban forest professionals around Florida were a resource of knowledge about wind resistance. In June 2005, we sent out 240 surveys to arborists, urban foresters, and forest scientists who were members of either the International Society of Arboriculture (Florida chapter) or the Florida Urban Forestry Council or faculty at the University of Florida asking them to rank the wind resistance (high, medium, or low) of those urban tree species they observed after hurricanes. Eighty-five surveys (35\%) were returned. We report these numbers and percentages in this publication and then use these ratings along with our measurements and analyses and the scientific literature to formulate wind resistance lists for tree species in urban areas.

\section{Statistical Analysis}

Data from all hurricanes were analyzed using the GLM, REG, LOGISTIC, and FREQ procedures of SAS. Only species with a sample size larger than or equal to 20 trees for each hurricane were included. PROC GLM was used for all survival and branch loss analyses. Species survival was modeled using species and neighborhoods with neighborhood considered a random effect. The error term used was the interaction of species and neighborhood. Multiple comparisons were used to compare survival means among species. For native versus exotic and cluster planting analyses, survival was modeled using them as a categorical variable and neighborhood was considered a random effect. The error term used was the interaction of the categorical variable and neighborhood. A t-test was used to compare survival with these variables. Frequency tables were used to describe if fallen trees were broken or uprooted and to describe property damage by species.

To analyze the relationship between leaf loss and survival, a logistic regression was conducted using the PROC LOGISTIC procedures in SAS with survival as the dependent variable and percentage of leaf loss as the explanatory variable. To determine if survival and branch damage were related to wood density, wood densities were grouped into four categories using the GLM procedure in SAS. A multiple comparison test was done for survival and branch damage between the categories.

A $\chi^{2}$ test was used to compare survival and excurrent versus decurrent growth using the FREQ procedure in SAS. Branch damage was modeled using SAS GLM, and a t-test compared the two growth types. For crown density, $\chi^{2}$ tests 
were used to compare survival. Branch damage was modeled using the GLM procedure in SAS with the particular crown density, and t-tests were used to compare branch damage. After comparing survival of palms and nonpalms, palms were removed from these analyses.

\section{RESULTS AND DISCUSSION}

\section{Overall Urban Forest Loss}

The percent of urban forest loss (mortality) was positively correlated with wind speed (Figure 2). Francis and Gillespie (1993) also related wind speed to urban tree damage from Hurricane Hugo in Puerto Rico and found that at $50 \mathrm{~km} / \mathrm{h}$ (31 $\mathrm{mph}$ ), there was no damage compared with $80 \%$ damage at $125 \mathrm{~km} / \mathrm{h}(78 \mathrm{mph})$ and $90 \%$ to $100 \%$ damage at $200 \mathrm{~km} / \mathrm{h}$ (124 mph). Some of the other factors that could explain the variation of tree loss include the speed that the hurricane moved through the area, soil conditions including soil depth and moisture, and the overall tree canopy and its health. Hurricane damage in natural forest ecosystems in the Caribbean has been found to be dependent on four factors: (1) the hurricane intensity including rainfall, (2) the storm size, (3) topography, and (4) the susceptibility of the ecosystem to damage (Tanner et al. 1991).

\section{Tree Survival and Branch Loss}

Tree species in the Southeastern Coastal Plain respond differently to hurricanes. Response of species to Hurricane Ivan in 2004 illustrates differences at $209 \mathrm{~km} / \mathrm{h}(130 \mathrm{mph})$ wind speeds (Figure 3). Tree species demonstrating the highest survival in these winds were sand live oak (Quercus geminata), American holly (Ilex opaca), southern magnolia (Magnolia grandiflora), live oak, wax myrtle (Myrica cerifera), sweetgum (Liquidambar styraciflua), crapemyrtle (Lager-

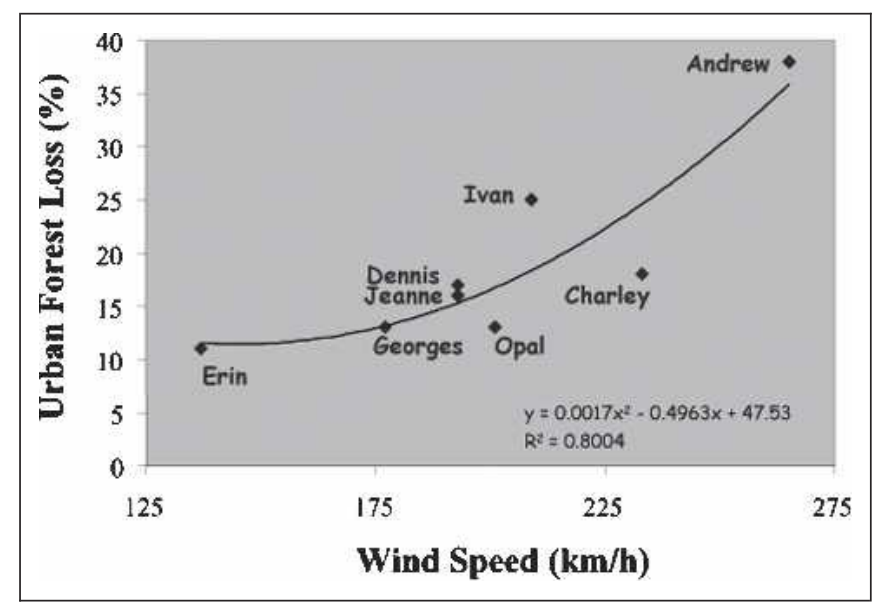

Figure 2. Urban forest loss (\%) increased with wind speed. A polynomial relationship with $R^{2}=0.80$ includes eight hurricanes.

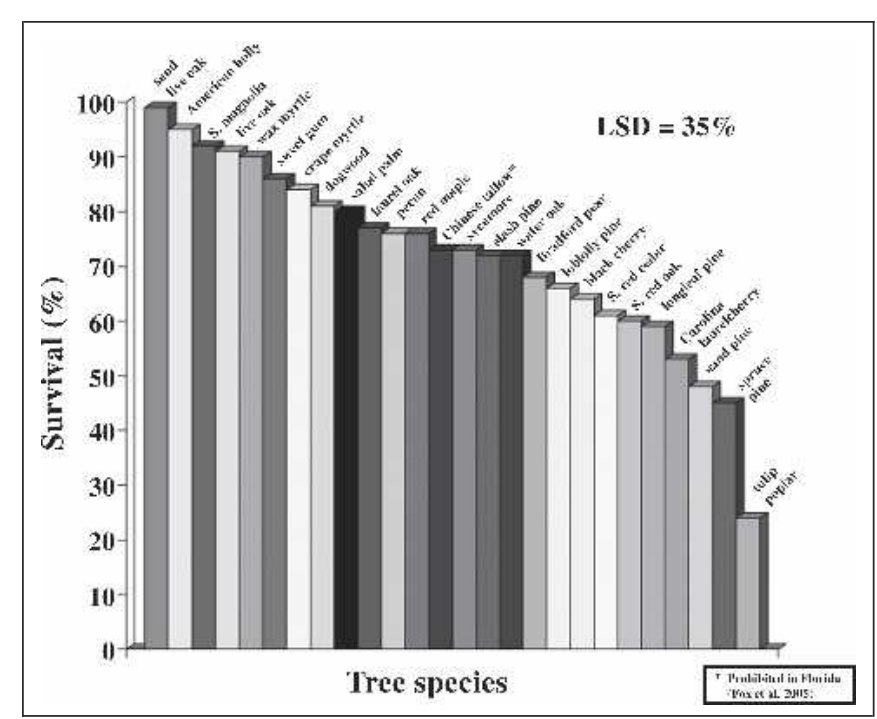

Figure 3. Survival (percent of trees standing after the hurricane) of tree species in Hurricane Ivan, which struck at $209 \mathrm{~km} / \mathrm{h}$ (130 mph). The least significant difference is at the 0.05 level.

stroemia indica), dogwood (Cornus florida), and sabal palm. Dogwood, live oak, sabal palm, sand live oak, and southern magnolia were also the best survivors in Hurricanes Erin and Opal in 1995 (Duryea 1997). A more detailed look at live oak and sabal palm demonstrates their repeated resilience to hurricane force winds (Table 1). However, it can also be seen that in south Florida, when the winds reached 233 and 265 $\mathrm{km} / \mathrm{h}$ (145 and $165 \mathrm{mph})$ in Hurricanes Charley and Andrew, survival of live oak decreased to $78 \%$. In a statistical comparison of sand live oak, live oak, and laurel oak, laurel oak had poorer overall survival than both live oak and sand live oak in four panhandle Florida hurricanes $(P<0.001)$ (Figure 4). In several publications, live oak, sabal palm, baldcypress (Taxodium distichum), and pondcypress (Taxodium ascendens) have been ranked at the top of lists for hurricane-related wind resistance (Touliatos and Roth 1971; Swain 1979; Barry et al. 1993).

Branch loss in hurricanes may also be an important measure of their resilience (Figure 5). In Hurricane Ivan, southern redcedar (Juniperus virginiana var. silicicola), sycamore (Platanus occidentalis), southern red oak (Quercus falcata), and laurel oak lost on average over $25 \%$ of their branches. Sweetgum, silver maple (Acer saccharinum), sycamore, and southern redcedar were species losing the most branches in Hurricanes Erin and Opal (Duryea 1997). Species with 10\% or less branch loss were crapemyrtle, loblolly pine (Pinus taeda), American holly, and tulip poplar (Liriodendron tulipifera). When we looked at tree diameter and branch loss, large trees (100 to $200 \mathrm{~cm}$ [40 to $80 \mathrm{in}$ ] diameter) lost the most branches (30\%), then medium-sized trees $(50$ to $99 \mathrm{~cm}$ 
Table 1. Survival (percent of trees standing after the hurricane) for Southeastern Coastal Plain species after six hurricanes ${ }^{2}$.

\begin{tabular}{|c|c|c|c|c|c|c|c|}
\hline \multirow{2}{*}{\multicolumn{2}{|c|}{ Tree species }} & \multicolumn{6}{|c|}{$\begin{array}{l}\text { Survival }(\%) \text { after each hurricane } \\
\text { (wind speed in } \mathrm{km} / \mathrm{h} \text { ) }\end{array}$} \\
\hline & & $\begin{array}{c}\text { Erin } \\
(137)\end{array}$ & $\begin{array}{l}\text { Jeanne } \\
(193)\end{array}$ & $\begin{array}{l}\text { Opal } \\
(201)\end{array}$ & $\begin{array}{l}\text { Ivan } \\
(209)\end{array}$ & $\begin{array}{l}\text { Charley } \\
(233)\end{array}$ & $\begin{array}{l}\text { Andrew } \\
(265)\end{array}$ \\
\hline \multicolumn{8}{|c|}{ Dicots } \\
\hline Acer rubrum & Red maple & - & - & 93 & 76 & - & - \\
\hline Acer saccharinum & Silver maple & - & - & 93 & - & - & - \\
\hline Carya floridana & Florida scrub hickory & - & 83 & - & - & - & - \\
\hline Carya illinoensis & Pecan & 97 & - & 93 & 76 & - & - \\
\hline Carya glabra & Pignut hickory & 100 & - & - & - & - & - \\
\hline Cinnamomum camphora ${ }^{\mathrm{x}}$ & Camphor & - & - & - & - & 90 & - \\
\hline Cornus florida & Flowering dogwood & 100 & - & 96 & 81 & - & - \\
\hline Ilex opaca & American holly & - & - & - & 95 & - & - \\
\hline Lagerstroemia indica & Crapemyrtle & - & - & - & 84 & - & - \\
\hline Liquidambar styraciflua & Sweetgum & - & - & 93 & 86 & - & - \\
\hline Liriodendron tulipifera & Tulip poplar & - & - & - & 24 & - & - \\
\hline Magnolia grandifolia & Southern magnolia & 96 & - & 97 & 92 & - & - \\
\hline Magnolia virginiana & Sweet bay magnolia & 97 & - & - & - & - & - \\
\hline Myrica cerifera & Wax myrtle & - & - & - & 90 & - & - \\
\hline Platanus occidentalis & Sycamore & - & - & 92 & 73 & - & - \\
\hline Prunus caroliniana & Carolina laurelcherry & 76 & - & 74 & 53 & - & - \\
\hline Prunus serotina & Black cherry & - & - & - & 64 & - & - \\
\hline Pyrus calleryana & Bradford pear & - & - & - & 68 & - & - \\
\hline Quercus falcata & Southern red oak & - & - & - & 60 & - & - \\
\hline Quercus virginiana & Live oak & 96 & 97 & 95 & 91 & 78 & 78 \\
\hline Quercus geminata & Sand live oak & 96 & 94 & 96 & 99 & - & - \\
\hline Quercus laurifolia & Laurel oak & 89 & 94 & 90 & 77 & 85 & - \\
\hline Quercus laevis & Turkey oak & 83 & - & 89 & - & - & - \\
\hline Quercus nigra & Water oak & - & - & - & 72 & - & - \\
\hline Sapium sebiferum ${ }^{\mathrm{y}}$ & Chinese tallow & 97 & - & 83 & 73 & - & - \\
\hline \multicolumn{8}{|c|}{ Monocots_Palms } \\
\hline Butia capitata & Jelly palm & 97 & - & - & - & - & - \\
\hline Sabal palmetto & Sabal palm & 97 & 92 & 100 & 80 & 92 & 93 \\
\hline Washingtonia robusta & Washington palm & - & 80 & - & - & 92 & - \\
\hline \multicolumn{8}{|c|}{ Conifers } \\
\hline $\begin{array}{l}\text { Juniperus virginiana } \\
\quad \text { var. silicicola }\end{array}$ & Southern redcedar & 92 & - & 60 & 61 & - & - \\
\hline Pinus clausa & Sand pine & 61 & 4 & 58 & 48 & - & - \\
\hline $\begin{array}{l}\text { Pinus elliottii } \\
\quad \text { var. elliottii and var. densa }\end{array}$ & $\begin{array}{l}\text { Slash pine } \\
\quad \text { (and South Florida slash pine) }\end{array}$ & 95 & 90 (var. densa) & 96 & 72 & 79 (var. densa) & 73 (var. densa) \\
\hline Pinus glabra & Spruce pine & - & - & - & 46 & - & - \\
\hline Pinus palustris & Longleaf pine & 90 & - & 94 & 59 & 57 & - \\
\hline Pinus taeda & Loblolly pine & - & - & 82 & 66 & - & - \\
\hline Taxodium distichum & Baldcypress & - & - & - & - & 95 & - \\
\hline
\end{tabular}

${ }^{\mathrm{z}}$ Numbers are presented only for tree species having a sample greater or equal to $n=20$ trees for each hurricane. Least significant differences at $P=0.05$ are $35 \%$ for Jeanne, 35\% for Ivan, and 30\% for Charley. Erin and Opal survival percentages are from Duryea (1997); Andrew survival percentages are from Duryea et al. (1996).

${ }^{\mathrm{y}}$ Prohibited from use in Florida.

${ }^{\mathrm{x}}$ Invasive and not recommended for use in Florida (Fox et al. 2005).

[20 to 39.6 in]) with $25 \%$ loss, smaller trees (20 to $49 \mathrm{~cm}[8$ to $19.6 \mathrm{in}])$ with $20 \%$, and the smallest trees $(<20 \mathrm{~cm}[<8$ in $])$ lost $12 \%$ of their branches $(P<0.0001)$. Glitzenstein and Harcombe (1988) also found that damage was positively cor- related with average stem size in a forest stand. In their review, Everham and Brokaw (1996) summarize that most researchers have found a positive correlation between stem size and wind damage. Webb (1989) found that larger trees were 


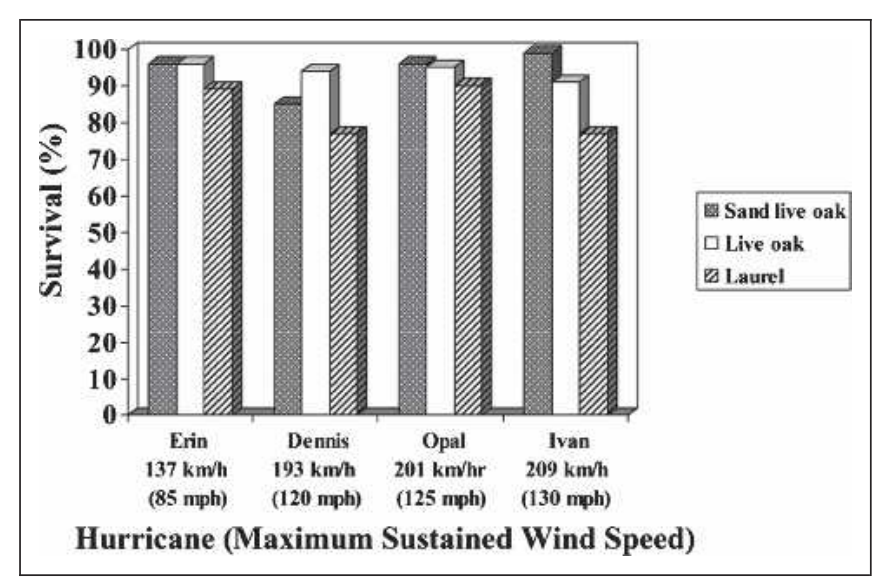

Figure 4. In a statistical comparison of sand live oak, live oak, and laurel oak survival in panhandle hurricanes, laurel oak survival was significantly less than the other two oaks $(P<0.001$ ). There was no difference between sand live oak and live oak survival.

more likely to be damaged directly by the wind compared with smaller trees, which were more likely to be indirectly damaged by other falling trees.

Because trees with large amounts of branch loss from a hurricane may not be considered healthy urban trees, we reanalyzed survival taking into account branches lost. Standing trees that had $50 \%$ or greater branch loss were called dead and a "new" survival was calculated (Figure 6). Some species with heavy branch loss had significantly lower recalculated survival. Southern redcedar survival was decreased from $61 \%$ to $46 \%$ as a result of heavy branch loss. Sycamore survival was reduced from $73 \%$ to $52 \%$. Even live oak trees had significant branch loss and their survival was decreased from

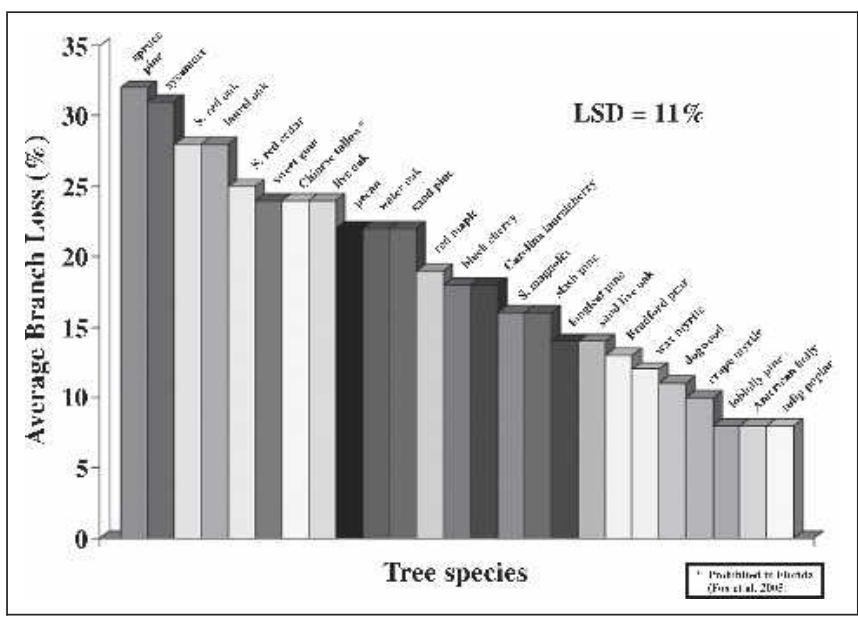

Figure 5. Average branch loss (\%) for each tree species in Hurricane Ivan, which struck land at $209 \mathrm{~km} / \mathrm{h}$ (130 mph). The least significant difference is at the 0.05 level.

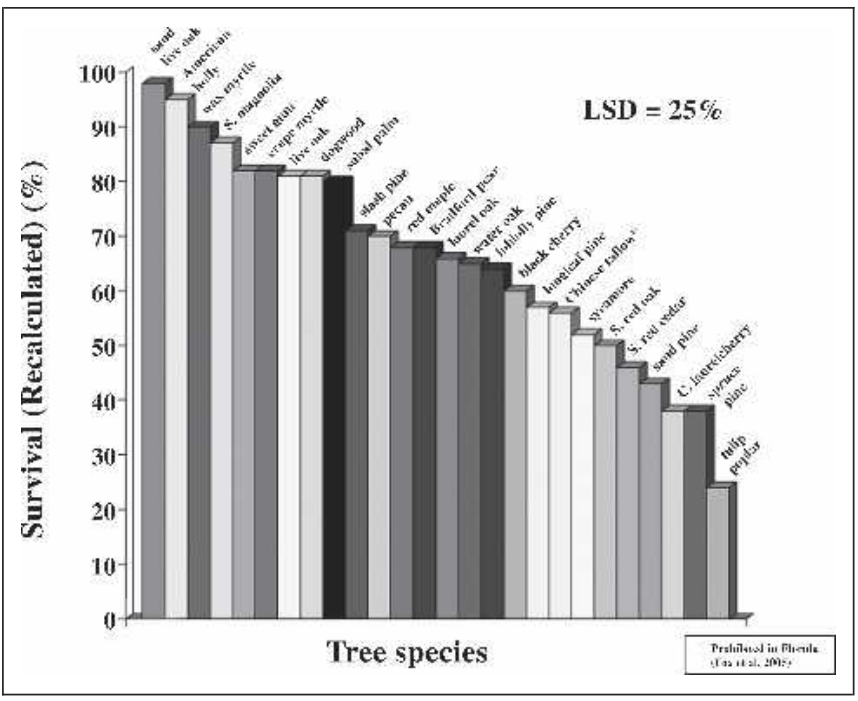

Figure 6. A recalculation of survival (\%) after calling trees with $\geq 50 \%$ branch loss as dead after Hurricane Ivan. The least significant difference is at the 0.05 level.

$91 \%$ to $81 \%$. When we statistically compared the recalculated survival of oak species after Hurricane Ivan, the ranking from greatest to lowest survival was sand live oak (98\% survival), live oak (81\%), laurel oak (66\%), water oak (Quercus nigra) $(65 \%)$, and Southern red oak $(50 \%)(P=0.0001)$. A study in South Carolina coastal plain forests after Hurricane Hugo found that live oak was less damaged than laurel and water oaks (Gresham et al. 1991).

Survival of pine species showed significant differences with greatest survival for slash pine (Pinus elliottii var. elliottii) (71\%), then loblolly (64\%), longleaf (Pinus palustris) (57\%), sand pine (Pinus clausa) $(43 \%)$, and spruce pine ( $\mathrm{Pi}$ nus glabra) (38\%) $(P=0.0014)$. Three months after Hurricane Ivan, we remeasured pines and found that $2 \%$ to $3 \%$ of the slash and longleaf standing trees had died and $56 \%$ of the standing sand pine had died. In the southeastern coastal plain forest, longleaf pine was less damaged than loblolly during Hurricane Hugo (12\% versus $73 \%$ damaged) (Gresham et al. 1991), but a tornado in Texas resulted in equal and intense damage to loblolly, longleaf, and shortleaf (Pinus echinata) pines (Glitzenstein and Harcombe 1988). Two conifer species that have shown repeatedly poor performance in our studies during hurricanes are sand pine and southern redcedar (Duryea 1997 ) (Table 1 ).

\section{Broken versus Uprooted}

Some species have a tendency to break at the stem compared with uprooting. In Hurricane Ivan, pecan (Carya illinoensis), sand pine, and sabal palm tended to uproot more than break (83\%, $77 \%$, and $90 \%$ uprooted, respectively). The other pines both uprooted and broke. This is in contrast to Hurricane 
Andrew in which $90 \%$ of the south Florida slash pine (Pinus elliottii var. densa) that fell broke (Duryea et al. 1996). Van Hooser and Hedlund (1969) also found that pines tended to snap compared with uprooting for broadleaf species. In tropical species, Putz et al. (1983) found that species with shorter, thicker stems and denser wood tended to uproot rather than to snap. However, in our study, when it did fall (only 9\% of the live oaks), live oak with its dense wood $\left(0.8 \mathrm{~g} / \mathrm{cm}^{3}\right)$ equally uprooted or broke.

\section{Property Damage}

Twenty percent $(20 \%)$ of the trees that fell damaged property in Hurricane Ivan. Of these, $74 \%$ damaged major property (house, power lines, screened enclosures, automobiles, and so on) and $26 \%$ damaged minor property (fences, sheds, sidewalks). Ten percent of the total damage was to power lines. The tree species causing the most damage were pines, pecan, tulip poplar, and laurel and water oaks. In Hurricanes Erin and Opal, laurel oak, longleaf pine, sand pine, and slash pine caused the most damage (between $11 \%$ and $18 \%$ damage) and smaller species such as laurelcherry (Prunus caroliniana) and southern redcedar caused the least damage (Duryea 1997).

\section{What Makes a Tree More Wind-Resistant?}

The goal of this research project is to attempt to determine what biological and cultural factors make trees more or less wind-resistant. By evaluating these factors, we can understand the differences between species (i.e., whether they have dense wood or defoliate quickly in wind) and between certain practices (such as planting trees in groups compared with individual tree plantings), which could result in a healthier and more wind-resistant urban forest.

\section{Defoliation}

There were distinct species differences in defoliation during Hurricane Ivan. Species such as sand live oak, crapemyrtle, and dogwood lost an average of $94 \%, 88 \%$, and $86 \%$, respectively, of their leaves compared with southern redcedar, wax myrtle, slash pine, longleaf pine, and loblolly pine, which lost $32 \%, 31 \%, 29 \%, 19 \%$, and $11 \%$ of their leaves, respectively (least significant difference $=17 \%$ ). Leaf loss had a positive relationship $(P<0.0001)$ with both survival and recalculated survival (trees with $\geq 50 \%$ branch loss excluded); in other words, losing leaves during the hurricane meant higher survival. Francis and Gillespie (1993), reporting on urban trees in Puerto Rico after Hurricane Hugo in 1989, also found that crown damage appeared to be avoided if the crown surface area was reduced quickly with leaf and twig loss during the hurricane. There are some exceptions to defoliation being a strategy for survival; southern magnolia, American holly, and sabal palm are all excellent survivors but they only lost $43 \%$, $34 \%$, and $27 \%$ of their leaves, respectively.

\section{Native and Exotic Species}

In the coastal plain area, exotic tree species made up $8 \%$ of the trees in the urban forest. The major exotic species were crapemyrtle, Chinese tallow (Sapium sebiferum) (a prohibited invasive species), camphor tree (Cinnamomum camphora) (an invasive species), Bradford pear (Pyrus calleryana), and palms such as pindo palm (Butia capitata) and Washington fan palm (Washingtonia robusta). As a group, native trees survived the same as exotic trees $(73 \%$ versus $77 \%$, not significantly different [NS] and lost the same amount of branches (20\% versus $15 \%$, NS) and leaves (58\% versus $60 \%$, NS). In contrast, after Hurricane Andrew struck south Florida, native trees survived winds better than nonnative trees (Duryea et al. 1996). Other studies have shown trends toward increased wind damage of exotic species in rural plantation forests (King 1945; Everham and Brokaw 1996).

\section{Wood Characteristics}

In a comparison of wood density and wind resistance, we found that tree species with higher wood density $\left(\mathrm{g} / \mathrm{cm}^{3}\right)$ had greater survival in Hurricane Ivan (Table 2). When trees with $50 \%$ or greater branch damage were also included as nonsurvivors and a new percent survival was calculated, this recalculated survival was also greater with higher wood density. Differences in branch loss for various wood densities were not as apparent (Table 2). In a study with 24 tropical species in Puerto Rico, Francis (2000) also found that trees were less likely to fail by uprooting or breakage if they had higher wood density. In addition, similar to our study in which live oak with a wood density of 0.8 has a high survival rate, Hook

Table 2. Survival and branch loss for tree species in Hurricane Ivan for different wood density classes².

\begin{tabular}{lllll}
\hline $\begin{array}{l}\text { Wood density } \\
\left(\mathrm{g} / \mathrm{cm}^{3}\right)\end{array}$ & $\begin{array}{l}\text { Sample size } \\
\text { (number of trees) }\end{array}$ & Survival $(\%)$ & $\begin{array}{l}\text { Survival }(\%) \\
\text { (recalculated by subtracting } \\
\text { trees with } \geq 50 \% \text { branch loss) }\end{array}$ & Branch loss $(\%)$ \\
\hline 0.8 to 0.89 & 240 & $94 \mathrm{a}$ & $87 \mathrm{a}$ & $20 \mathrm{ab}$ \\
0.6 to 0.69 & 197 & $78 \mathrm{~b}$ & $73 \mathrm{~b}$ & $18 \mathrm{~b}$ \\
0.5 to 0.59 & 703 & $73 \mathrm{bc}$ & $66 \mathrm{c}$ & $23 \mathrm{a}$ \\
0.4 to 0.49 & 607 & $69 \mathrm{c}$ & $62 \mathrm{c}$ & $19 \mathrm{~b}$ \\
\hline
\end{tabular}

${ }^{\mathrm{z}}$ Numbers in columns with different letters are significantly different at $P=0.05$. No tree species occurred in the 0.7 to 0.79 class. 
Table 3. Survival and branch loss for tree species in Hurricane Ivan for different modulus of elasticity classes².

\begin{tabular}{|c|c|c|c|c|}
\hline $\begin{array}{l}\text { Modulus of elasticity } \\
(\mathrm{MPa})\end{array}$ & $\begin{array}{l}\text { Sample size } \\
\text { (number of trees) }\end{array}$ & Survival (\%) & $\begin{array}{l}\text { Survival }(\%) \\
\text { (recalculated by subtracting } \\
\text { trees with } \geq 50 \% \text { branch loss) }\end{array}$ & Branch loss $(\%)$ \\
\hline$\geq 10,000$ & 659 & $77 \mathrm{a}$ & $72 \mathrm{a}$ & $19 \mathrm{ab}$ \\
\hline 9,000 to 9,999 & 590 & $75 \mathrm{a}$ & 66 a & $24 \mathrm{a}$ \\
\hline 8,000 to 8,999 & 157 & $74 \mathrm{a}$ & $73 \mathrm{a}$ & $12 \mathrm{c}$ \\
\hline 7,000 to 7,999 & 213 & $74 \mathrm{a}$ & $66 \mathrm{a}$ & $20 \mathrm{~b}$ \\
\hline$<7,000$ & 126 & $63 \mathrm{~b}$ & $52 \mathrm{~b}$ & $22 \mathrm{ab}$ \\
\hline
\end{tabular}

${ }^{\mathrm{z}}$ Numbers in columns with different letters are significantly different at $P=0.05$.

et al. (1991) noted that the strong wood of live oak resulted in lost branches only and little windthrow during Hurricane Hugo in South Carolina. Putz et al. (1983) found that tree species with shorter, thicker stems and denser wood tended to uproot instead of break and that species with low-density wood had higher mortality.

Two other measurements of wood strength are the modulus of elasticity (Young's elastic modulus) and the modulus of rupture. The modulus of elasticity measures the wood's stiffness; after applying a certain weight (in MPa), it measures whether the wood recovers to its original position (Forest Products Laboratory 1999; Niklas 1999). Tree species with the highest modulus of elasticity $(>7,000 \mathrm{MPa})$ survived Hurricane Ivan better than those with the lowest values $(<7,000$ $\mathrm{MPa}$ ) (Table 3). Examples of species with the highest modulus of elasticity are slash pine, longleaf pine, sand live oak, and live oak $(10,500,11,000,10,900$, and $10,900 \mathrm{MPa}$, respectively). Those with the lowest modulus of elasticity are southern redcedar and spruce pine $(6,410$ and 6,900 MPa). Branch loss did not appear to be related. Niklas (1999) compared young black locust (Robinia pseudoacacia) with older trees and found that younger trees were less stiff and strong as a result of the different proportions of primary and secondary tissues as trees age.

Modulus of rupture is a measure of the bending stress that wood can experience without mechanically failing (Forest Products Laboratory 1999; Niklas 1999). Results from Hurricane Ivan show that survival was highest for those species with the highest modulus of rupture $(\geq 70,000 \mathrm{kPa})$, whereas branch loss showed no relationship (Table 4). Examples of species with low survival rates that have a low modulus of rupture were tulip poplar, spruce pine, and sycamore $(41,000$, 41,000, and 45,000 kPa). However, some species with high survival also have a low modulus of rupture (southern magnolia [47,000 kPa] and sweetgum [49,000 kPa]). Live oak and sand live oak represent the highest modulus of rupture category with $82,000 \mathrm{kPa}$. In a study with Scots pine (Pinus sylvestris), Skatter and Kucera's (2000) results supported the modulus of rupture as important to a tree's susceptibility to wind.

\section{Crown Characteristics}

Crown density is an estimate of the openness of the crown or the ratio of positive and negative space within the crown (Hightshoe 1988; Gilman 2005). We determined from the literature and observation the density class of each species and then compared open with moderate with dense crowns for branch loss and survival (Hightshoe 1988; Gilman 2005). Dense crowns had significantly greater survival than moderate or open crowns (84\% versus $74 \%$ versus $67 \%)(P<$ 0.0001 ). When we recalculated survival (excluding trees with $50 \%$ or greater branch loss), the relationship was still the same and significant $(75 \%, 68 \%$, and $62 \%)(P<0.0001)$. In contrast to our survival results, Foster (1988) concluded that after a catastrophic wind in New England, tree species with full crowns and shallow roots were more susceptible than those with a vertical distribution of canopy, flexible branches, and tapering shape. In their literature review, Everham and Brokaw (1996) summarized that there is a tendency for dense-crowned trees to be damaged and open-foliage crowns

Table 4. Survival and branch loss for tree species in Hurricane Ivan for different modulus of rupture classes ${ }^{2}$.

\begin{tabular}{llll}
\hline $\begin{array}{l}\text { Modulus of rupture } \\
(\mathrm{kPa})\end{array}$ & $\begin{array}{l}\text { Sample size } \\
\text { (number of trees) }\end{array}$ & Survival $(\%)$ & $\begin{array}{l}\text { Survival }(\%) \\
\text { (recalculated by subtracting } \\
\text { trees with } \geq 50 \% \text { branch loss) }\end{array}$ \\
\hline$\geq 70,000$ & 240 & $94 \mathrm{a}$ & $87 \mathrm{a}$ \\
60,000 to 60,999 & 486 & $74 \mathrm{bc}$ & $70 \mathrm{~b}$ \\
50,000 to 50,999 & 722 & $69 \mathrm{c}$ & $60 \mathrm{c}$ \\
$<50,000$ & 246 & $75 \mathrm{~b}$ & $68 \mathrm{~b}$ \\
\hline
\end{tabular}

${ }^{\mathrm{z}}$ Numbers in columns with different letters are significantly different at $P=0.05$. 
Table 5. Results of the survey of arborists, scientists, and urban foresters in Florida with their rankings for wind resistance of southeastern United States coastal plain tree species ${ }^{2}$.

\begin{tabular}{|c|c|c|c|c|c|c|c|c|c|}
\hline \multirow[b]{3}{*}{ Scientific name } & \multirow[b]{3}{*}{ Common name } & \multicolumn{6}{|c|}{ Wind resistance } & \multirow[b]{3}{*}{$P$ value } & \multirow[b]{3}{*}{ Total $n$} \\
\hline & & \multicolumn{2}{|c|}{ High } & \multicolumn{2}{|c|}{ Medium } & \multicolumn{2}{|c|}{ Low } & & \\
\hline & & $\mathrm{n}$ & Percent & $\mathrm{n}$ & Percent & $\mathrm{n}$ & Percent & & \\
\hline \multicolumn{10}{|l|}{ Dicots } \\
\hline Acer negundo & Boxelder & 1 & 8 & 6 & 50 & 5 & 42 & NS & 12 \\
\hline Acer palmatum & Japanese maple & 6 & 50 & 6 & 50 & 0 & 0 & NS & 12 \\
\hline Acer rubrum & Red maple & 12 & 20 & 32 & 52 & 17 & 28 & 0.0049 & 61 \\
\hline Acer saccharinum & Silver maple & 0 & 0 & 10 & 45 & 12 & 55 & NS & 22 \\
\hline Acer saccharum subsp floridanum & Florida sugar maple & 2 & 11 & 11 & 61 & 5 & 28 & 0.0302 & 18 \\
\hline Betula nigra & River birch & 11 & 39 & 16 & 57 & 1 & 4 & 0.0019 & 28 \\
\hline Carpinus caroliniana & Ironwood & 7 & 50 & 6 & 43 & 1 & 7 & NS & 14 \\
\hline Carya glabra & Pignut hickory & 11 & 41 & 14 & 52 & 2 & 7 & 0.0131 & 27 \\
\hline Carya illinoinensis & Pecan & 6 & 21 & 9 & 32 & 13 & 47 & NS & 28 \\
\hline Carya tomentosa & Mockernut hickory & 6 & 50 & 6 & 50 & 0 & 0 & NS & 12 \\
\hline Celtis laevigata & Sugarberry & 4 & 15 & 18 & 70 & 4 & 15 & 0.0005 & 26 \\
\hline Celtis occidentalis & Common hackberry & 2 & 18 & 5 & 46 & 4 & 36 & NS & 11 \\
\hline Cercis canadensis & Redbud & 14 & 48 & 8 & 28 & 7 & 24 & NS & 29 \\
\hline Chionanthus virginicus & Fringe tree & 7 & 50 & 5 & 36 & 2 & 14 & NS & 14 \\
\hline Cornus florida & Flowering dogwood & 9 & 60 & 6 & 40 & 0 & 0 & NS & 15 \\
\hline$\times$ Cupressocyparis leylandii & Leyland cypress & 7 & 22 & 13 & 41 & 12 & 37 & NS & 32 \\
\hline Diospyros virginiana & Common persimmon & 14 & 56 & 9 & 36 & 2 & 8 & 0.0128 & 25 \\
\hline Eucalyptus cinerea & Silver dollar eucalyptus & 2 & 13 & 9 & 56 & 5 & 31 & NS & 16 \\
\hline Eriobotrya japonica $^{\mathrm{y}}$ & Loquat & 9 & 24 & 24 & 63 & 5 & 13 & 0.0004 & 38 \\
\hline Fraxinus americana & White ash & 3 & 30 & 6 & 60 & 1 & 10 & NS & 10 \\
\hline Fraxinus pennsylvanica & Green ash & 3 & 24 & 5 & 38 & 5 & 38 & NS & 13 \\
\hline Ilex cassine & Dahoon holly & 34 & 76 & 10 & 22 & 1 & 2 & 0.0001 & 46 \\
\hline Ilex ораса & American holly & 21 & 75 & 6 & 21 & 1 & 4 & 0.0001 & 28 \\
\hline Ilex vomitoria & Yaupon holly & 28 & 81 & 7 & 19 & 0 & 0 & 0.0004 & 37 \\
\hline Juniperus silicicola & Southern redcedar & 14 & 28 & 18 & 35 & 19 & 37 & NS & 51 \\
\hline Lagerstroemia indica & Crapemyrtle & 55 & 83 & 11 & 17 & 0 & 0 & 0.0001 & 66 \\
\hline Liriodendron tulipifera & Tulip poplar & 2 & 8 & 14 & 58 & 8 & 33 & 0.0111 & 24 \\
\hline Liquidambar styraciflua & Sweetgum & 18 & 43 & 21 & 50 & 3 & 7 & 0.0013 & 42 \\
\hline Magnolia grandiflora & Southern magnolia & 45 & 82 & 9 & 16 & 1 & 2 & 0.0001 & 55 \\
\hline Magnolia virginiana & Sweetbay magnolia & 15 & 42 & 17 & 47 & 4 & 11 & 0.0169 & 36 \\
\hline Magnolia $\times$ soulangiana & Saucer magnolia & 8 & 44 & 9 & 50 & 1 & 6 & 0.0421 & 18 \\
\hline Morus rubra & Red mulberry & 6 & 23 & 14 & 54 & 6 & 23 & NS & 26 \\
\hline Myrica cerifera & Wax myrtle & 18 & 33 & 15 & 28 & 21 & 39 & NS & 54 \\
\hline Nyssa aquatica & Water tupelo & 7 & 58 & 5 & 42 & 0 & 0 & NS & 12 \\
\hline Nyssa sylvatica & Black tupelo & 14 & 58 & 9 & 38 & 1 & 4 & 0.0469 & 24 \\
\hline Ostrya virginiana & American hophornbeam & 8 & 67 & 4 & 33 & 0 & 0 & NS & 12 \\
\hline Persea borbonia & Redbay & 12 & 36 & 12 & 36 & 9 & 28 & NS & 33 \\
\hline Pinus clausa & Sand pine & 3 & 7 & 7 & 16 & 34 & 77 & 0.0001 & 44 \\
\hline Pinus glabra & Spruce pine & 7 & 54 & 1 & 8 & 5 & 38 & NS & 13 \\
\hline Pinus elliottii var. elliottii & Slash pine & 16 & 25 & 36 & 57 & 11 & 18 & 0.0002 & 63 \\
\hline Pinus palustris & Longleaf pine & 23 & 56 & 13 & 32 & 5 & 12 & 0.0017 & 41 \\
\hline Pinus taeda & Loblolly pine & 7 & 20 & 19 & 54 & 9 & 26 & 0.0289 & 35 \\
\hline Platanus occidentalis & Sycamore & 17 & 38 & 21 & 48 & 6 & 14 & NS & 44 \\
\hline Prunus angustifolia & Chickasaw plum & 12 & 50 & 8 & 33 & 4 & 17 & NS & 24 \\
\hline Prunus caroliniana & Carolina laurelcherry & 5 & 16 & 15 & 48 & 11 & 36 & NS & 31 \\
\hline Prunus serotina & Black cherry & 4 & 18 & 10 & 46 & 8 & 36 & NS & 22 \\
\hline Pyrus calleryana & Bradford pear & 5 & 21 & 5 & 21 & 14 & 58 & 0.0342 & 24 \\
\hline Quercus alba & White oak & 6 & 55 & 5 & 45 & 0 & 0 & 0.0539 & 11 \\
\hline Quercus falcata & Southern red oak & 4 & 20 & 15 & 75 & 1 & 5 & 0.0003 & 20 \\
\hline Quercus geminata & Sand live oak & 36 & 92 & 2 & 5 & 1 & 3 & 0.0001 & 39 \\
\hline Quercus laevis & Turkey oak & 17 & 47 & 16 & 45 & 3 & 8 & 0.0062 & 36 \\
\hline
\end{tabular}


Table 5. Results of the survey of arborists, scientists, and urban foresters in Florida with their rankings for wind resistance of southeastern United States coastal plain tree species ${ }^{2}$. (continued)

\begin{tabular}{|c|c|c|c|c|c|c|c|c|c|}
\hline \multirow[b]{3}{*}{ Scientific name } & \multirow[b]{3}{*}{ Common name } & \multicolumn{6}{|c|}{ Wind resistance } & \multirow[b]{3}{*}{$P$ value } & \multirow[b]{3}{*}{ Total $n$} \\
\hline & & \multicolumn{2}{|c|}{ High } & \multicolumn{2}{|c|}{ Medium } & \multicolumn{2}{|c|}{ Low } & & \\
\hline & & $\mathrm{n}$ & Percent & $\mathrm{n}$ & Percent & $\mathrm{n}$ & Percent & & \\
\hline Quercus laurifolia & Laurel oak & 3 & 4 & 27 & 39 & 39 & 57 & 0.0001 & 69 \\
\hline Quercus michauxii & Swamp chestnut oak & 8 & 50 & 8 & 50 & 0 & 0 & NS & 16 \\
\hline Quercus myrtifolia & Myrtle oak & 13 & 76 & 4 & 24 & 0 & 0 & 0.0290 & 17 \\
\hline Quercus nigra & Water oak & 3 & 8 & 14 & 36 & 22 & 56 & 0.0009 & 39 \\
\hline Quercus phellos & Willow oak & 1 & 8 & 8 & 67 & 3 & 25 & 0.0388 & 12 \\
\hline Quercus shumardii & Shumard oak & 13 & 52 & 10 & 40 & 2 & 8 & 0.0207 & 25 \\
\hline Quercus stellata & Post oak & 5 & 33 & 10 & 67 & 0 & 0 & NS & 15 \\
\hline Quercus virginiana & Live oak & 64 & 89 & 8 & 11 & 0 & 0 & 0.0001 & 72 \\
\hline Salix $\times$ sepulcralis & Weeping willow & 2 & 12 & 8 & 50 & 6 & 38 & NS & 16 \\
\hline Taxodium distichum & Baldcypress & 59 & 91 & 6 & 9 & 0 & 0 & 0.0001 & 65 \\
\hline Taxodium ascendens & Pondcypress & 41 & 91 & 4 & 9 & 0 & 0 & 0.0001 & 45 \\
\hline Tilia americana & Basswood & 5 & 38 & 4 & 31 & 4 & 31 & NS & 13 \\
\hline Ulmus alata & Winged elm & 15 & 53 & 12 & 43 & 1 & 4 & 0.0030 & 28 \\
\hline Ulmus americana & American elm & 6 & 30 & 12 & 60 & 2 & 10 & 0.0224 & 20 \\
\hline Ulmus parvifolia & Chinese elm & 7 & 23 & 11 & 35 & 13 & 42 & NS & 31 \\
\hline Vaccinium arboreum & Sparkleberry & 11 & 85 & 2 & 15 & 0 & 0 & 0.0126 & 13 \\
\hline \multicolumn{10}{|l|}{ Palms } \\
\hline Butia capitata & Pindo, jelly & 34 & 79 & 7 & 16 & 2 & 5 & 0.0001 & 43 \\
\hline Phoenix canariensis & Canary Island date palm & 49 & 89 & 4 & 7 & 2 & 4 & 0.0001 & 55 \\
\hline Phoenix dactylifera & Date palm & 33 & 94 & 2 & 6 & 0 & 0 & 0.0001 & 35 \\
\hline Sabal palmetto & Cabbage, sabal palm & 71 & 99 & 1 & 1 & 0 & 0 & 0.0001 & 72 \\
\hline Washingtonia robusta & Washington fan palm & 29 & 54 & 16 & 29 & 9 & 17 & 0.0033 & 54 \\
\hline
\end{tabular}

$\mathrm{z}_{\mathrm{n}}$ is the number of respondents for each species out of a total of 85 experts. $P$ values from the $\chi^{2}$ test for equal proportions indicate the significance level for one or more of the categories being different from the others; NS means that there is no significant difference between the categories of high, medium, and low $(P>0.05)$.

${ }^{\mathrm{y}}$ Caution: may be used but manage to prevent escape because of possible invasiveness (Fox et al. 2005).

to be spared. Our results did agree with the literature for branch damage; tree species with dense crowns lost more branches (24\% branch loss) than those with moderate and open crowns $(19 \%$ and $18 \%)(P<0.0001)$. Some of the dense-crown species are live oak, sand live oak, laurel oak, American holly, and Bradford pear. Red maple (Acer rubrum), dogwood, crapemyrtle, sweetgum, southern magnolia, water oak, and red oak have moderately dense crowns. Examples of open crowns are the pines, pecan, southern redcedar, and wax myrtle.

The growth form of a tree can be categorized as excurrent or decurrent. Excurrent trees have strong apical dominance with the main trunk present throughout the life of the tree (giving rise to cone-shaped crowns with a central trunk). Decurrent trees have lateral branches that grow as rapidly as the central trunk; they have no dominant main leader (Harris et al. 2004). Decurrent trees had significantly higher survival (80\%) compared with excurrent trees (69\%). Recalculated survival (excluding those with heavy branch loss) of decurrent species was less different than excurrent trees but it was still significant ( $72 \%$ versus $64 \%, P=0.0005$ ). However, decurrent species experienced more branch damage than excurrent $(22 \%$ versus $17 \%, P<0.0001)$. Examples of decurrent trees in the southeastern coastal plain are pecan, dogwood, crapemyrtle, oaks, and wax myrtle. Excurrent trees include pines, American holly, sweetgum, southern redcedar, tulip poplar, and southern magnolia.

\section{Trees Growing in Groups}

We hypothesized that trees growing in groups or clusters might survive hurricane force winds better. A group was defined as five or more trees each growing within $3 \mathrm{~m}$ of another tree (but not in a row). Trees growing in groups had $80 \%$ survival during Hurricane Ivan compared with $70 \%$ for those growing as individual trees $(P=0.0002)$. Trees growing in groups also lost significantly more leaves than individual trees (63\% leaf loss versus $55 \%, P=0.0001)$. Branch loss, however, was the same for trees in groups and individuals (19\% and 20\%, NS).

\section{The Survey}

Arborists' and urban foresters' ratings of wind resistance for coastal plain species show a strong agreement with our mea- 
surements over several hurricanes. Small trees that were awarded high wind resistance ratings were fringe tree (Chionanthus virginicus), dogwood, persimmon (Diospyros virginiana), myrtle oak (Quercus myrtifolia), sparkleberry (Vaccinium arboretum), and the hollies (Ilex spp.) (Table 5). Although live oak and sand live oak were rated as high, other oaks such as southern red oak and swamp chestnut oak (Quercus michauxii) were rated as medium and, in agreement with our results, laurel and water oaks were rated as having low wind resistance. Although we have consistently seen southern redcedar to have low survival or heavy branch damage, the ratings were very even for each of the wind-resistant categories in the survey results. However, $91 \%$ of the respondents rated baldcypress and pondcypress with high wind resistance. Both cypresses were stated to have the best wind resistance along with live oak and sabal palm after Hurricanes Camille and Frederick struck the Gulf Coast in 1969 and 1979 (Swain 1979). In the survey, sand pine received a low rating, which is consistent with our results, whereas the other pines mostly were rated as medium, again consistent with our results. Everham and Brokaw (1996) in their summarizing list of wind resistance for forest species cite 10 studies in which loblolly, slash, and longleaf pines are ranked with low to intermediate wind resistance. Sabal palm received a high wind-resistant rating from $99 \%$ of the survey respondents in agreement with our ratings and those of Swain (1979). One palm, Canary Island date palm (Phoenix canariensis), which is being planted more frequently in north Florida, received a high rating from $89 \%$ of the respondents.

Sweetgum was rated as medium to high wind resistance by respondents; in a summary table of wind resistance by Everham and Brokaw (1996), seven studies rated sweetgum as medium to high wind resistance. Our studies have shown that it survives well but is prone to some branch breakage. In a Texas study after a tornado, sweetgum was listed as one of the best survivors but also a tree with the most branch damage (Glitzenstein and Harcombe 1988). In a study after Hurricane Kate in 1985, sweetgum had low mortality (2\%) in a southern mixed hardwood forest compared with spruce pine with $34 \%$ mortality (Batista and Platt 2003). They note that windfirmness of sweetgum is likely the result of its underground connections, short and stout branches, and leaves with slender

Dicots Highest Wind Resistance
$\quad$ Carya floridana, FL scrub hickory
$\quad$ Cornus florida, dogwood
Ilex cassine, dahoon holly
Ilex glabra, inkberry

Figure 7. Wind resistance of southeastern coastal plain species as estimated using the results of hurricane measurements in this study, the survey results of this study, and the scientific literature cited throughout this publication. 
long petioles that readily detach from branches in wind. On gravelly ridges, hillsides, and upland piedmont sites, sweetgum has been noted to develop a particularly strong tap root and is very resistant to wind (Kormanik 1990).

Tulip poplar had very poor survival in Hurricane Ivan (24\%). Respondents from the survey rated it as medium to low wind resistance. Everham and Brokaw (1996) summarize two studies in their table with high levels of wind damage for tulip poplar in high-intensity storms.

\section{IMPLICATIONS FOR ARBORICULTURE AND URBAN FORESTRY}

Taking our survival and branch loss results from hurricanes and incorporating results from the survey and from the scientific literature, we have developed lists of relative wind resistance for tree species in the southeastern coastal plain (Figure 7). These lists should be used with caution with the knowledge that no species and no tree is completely windproof. In addition, local considerations such as soil, cultural practices, tree age and health, and other urban forest health conditions need to be taken into account. In addition to hur- ricane wind speed, other conditions accompanying hurricanes such as precipitation and the speed in which they move through an area appear to influence tree response.

Additional recommendations for establishing new trees include:

- Planting a mixture of species, ages, and layers (shrubs and trees) to maintain diversity in your community;

- Planting trees from the "highest" and "medium-high" wind resistance lists and matching these to local site conditions;

- Giving trees adequate rooting space with no obstructions (e.g., sidewalks, buildings, streets);

- For small trees, provide at least $3 \mathrm{~m}(9.9 \mathrm{ft})$ by $3 \mathrm{~m}(9.9$ $\mathrm{ft})$;

- For large trees, provide at least $10 \mathrm{~m}(33 \mathrm{ft})$ by $10 \mathrm{~m} \mathrm{(33}$ $\mathrm{ft})$;

- Considering planting tree in groups as opposed to individually;

- Considering soil properties when deciding what to plant (e.g., soil depth, water table depth, and compaction); and

\begin{tabular}{|c|c|}
\hline & Medium-Low Wind Resistance \\
\hline \multicolumn{2}{|c|}{ Dicots } \\
\hline$>$ & Acer negundo, boxelder \\
\hline$>$ & Acer rubrum, red maple \\
\hline$>$ & Acer saccharinum, silver maple \\
\hline$>$ & Celtis Iaevigata, sugarberry \\
\hline$>$ & Celtis occidentalis, hackberry \\
\hline$>$ & Cinnamomum camphora, camphor** \\
\hline - & Eriobotrya japonica, loquat $* * *$ \\
\hline$>$ & Eucalyptus cinerea, silverdollar eucalyptus \\
\hline$>$ & Fraxinus pennsy/vanica, green ash \\
\hline$>$ & Morus rubra, red mulberry \\
\hline$>$ & Myrica cerifera, wax myrtle \\
\hline$>$ & Persea horbonia, redbay \\
\hline$>$ & Platanus occidentalis, sycamore \\
\hline$>$ & Prunus serotina, black cherry \\
\hline$>$ & Quercus alba, white oak \\
\hline$>$ & Quercus phellos, willow oak \\
\hline$>$ & Salix $\times$ sepulcralis, wecping willow \\
\hline$>$ & Ulmus americana, American elm \\
\hline \multicolumn{2}{|c|}{ Conifers } \\
\hline$\nu$ & Pinus elliottii var. elliottii, slash pine \\
\hline$>$ & Pinus palustris, longleaf pine \\
\hline > & Pinus taeda, loblolly pine \\
\hline
\end{tabular}

\section{Lowest Wind Resistance}

Dicots

> Carya illinoensis, pecan

- Liriodendron tulipifera, tulip poplar

> Pranas caroliniana, Carolina laurelcherry

- Pyrus calleryana, Bradford pear

$>\quad$ Quercus falcata, southern red oak

> Quercus laurifolia, laurel oak

- Quercus nigra, water oak

- Sapium sebiferum, Chinese tallow*

- Ulmus parvifolia, Chinese elm

Conifers

- Juniperus silicicola, southern red cedar

$>\quad$ x Cupressocyparis leylandit, Leyland cypress

$>\quad$ Pinus clausa, sand pine

> Pinus glabra, spruce pine

Palms

- Woshingtonia robusta, Washington fan

Figure 7. (continued) 
- Giving trees adequate aerial space considering their crown size when mature.

Recommendations for managing established trees include:

- Having tree health evaluated and removing hazard trees;

- Considering removing trees that are on the "lowest wind resistance" list, especially if they are overmature and endangering life or property;

- Establishing a regular structural pruning program (especially for dicots);

- Not overpruning palms, especially before a hurricane; palms only need to have dead or dying leaves removed;

- Being aware of possible root damage (and lack of anchoring) when construction has resulted in sidewalks or trenches near the roots of trees;

- Avoiding damage to the trunk of the tree (e.g., mechanical weed control damage); and

- Consulting with an ISA-Certified Arborist.

Acknowledgments. This project was partially funded by the Florida Department of Transportation. We are grateful to Jeff English and Meghan Brennan for help in the field and during the statistical analyses and Rick Joyce for his support of this study.

\section{LITERATURE CITED}

Barry, P.J., C. Doggett, R.L. Anderson, and K.M. Swain Sr. 1993. How to evaluate and manage storm-damaged forest areas. Management Bulletin R8-MB 63 of the USDA Forest Service, Southern Region. Atlanta, GA. 11 pp.

Batista, W.B., and W.J. Platt. 2003. Tree population responses to hurricane disturbance: Syndromes in a southeastern USA old-growth forest. Ecology 91:197-212.

Cremer, K.W., C.J. Borough, F.H. McKinnell, and P.R. Carter. 1982. Effects of stocking and thinning on wind damage in plantations. New Zealand Journal of Forestry Science 12:244-268.

Curtis, J.D. 1943. Some observations on wind damage. Journal of Forestry 41:877-882.

Duryea, M.L. 1997. Wind and trees: Surveys of tree damage in the Florida Panhandle after Hurricanes Erin and Opal. Circular 1183 of the University of Florida Cooperative Extension Service. http://edis.ifas.ufl.edu/ (accessed 3/8/06). Gainesville, FL. 7 pp.

Duryea, M.L., G.M. Blakeslee, W.G. Hubbard, and R.A. Vasquez. 1996. Wind and trees: A survey of homeowners after Hurricane Andrew. Journal of Arboriculture 22: 44-50.

Everham, E.M. III, and N.V.L. Brokaw. 1996. Forest damage and recovery from catastrophic wind. Botanical Review 62:113-185.

Forest Products Laboratory. 1999. Wood handbook-Wood as an engineering material. Gen. Tech. Rep. FPL-GTR-
113 of the USDA Forest Service Forest Products Laboratory. Madison, WI. 463 pp.

Foster, D.R. 1988. Species and stand response to catastrophic wind in central New England, U.S.A. Journal of Ecology 76:135-151.

Fox, A.M., D.R. Gordon, J.A. Dusky, L. Tyson, and R.K. Stocker. 2005. IFAS assessment of the status of nonnative plants in Florida's natural areas. SS-AGR-225 of the University of Florida IFAS Cooperative Extension Service. http://plants.ifas.ufl.edu/assessment.html (accessed 3/8/06). Gainesville, FL. 27 pp.

Francis, J.K. 2000. Comparison of hurricane damage to several species of urban trees in San Juan, Puerto Rico. Journal of Arboriculture 26:189-197.

Francis, J.K., and A.J.R. Gillespie. 1993. Relating gust speed to tree damage in Hurricane Hugo, 1989. Journal of Arboriculture 19:368-372.

Gilman, E. 2005. Tree selection for landscapes. Web site with 680 Tree Fact Sheets: http://hort.ifas.ufl.edu/woody/ planting/TreeSelectionIntroduction.htm (accessed 3/8/06) of the University of Florida Cooperative Extension Service. Gainesville, FL.

Glitzenstein, J.S., and P.A. Harcombe. 1988. Effects of the December 1983 tornado on forest vegetation of the Big Thicket, southeast Texas, USA. Forest ecology and management 25:269-290.

Gresham, C.A., T.M. Williams, and D.J. Lipscomb. 1991. Hurricane Hugo wind damage to Southeastern U.S. coastal forest tree species. Biotropica 23(4) (Part A. Special Issue: Ecosystem, Plant, and Animal Responses to Hurricanes in the Caribbean):420-426.

Harris, R.W., J.R. Clark, and N.P. Matheny. 2004. Arboriculture: Integrated Management of Landscape Trees, Shrubs, and Vines. 4th ed. Prentice-Hall, Upper Saddle River, NJ. 580 pp.

Hightshoe, G.L. 1988. Native trees, shrubs, and vines for urban and rural America: A planting design manual for environmental designers. Van Nostrand Reinhold, New York, NY. 819 pp.

Hook, D.D., M.A. Buford, and T.M. Williams. 1991. Impact of Hurricane Hugo on the South Carolina coastal plain forest. Journal of Coastal Research (Special issue) 8: 291-300.

Jim, C.Y., and H.H.T. Liu. 1997. Storm damage on urban trees in Guangzhou, China. Landscape and Urban Planning 38:45-59.

King, H.C. 1945. Notes on the three cyclones in Mauritius in 1945: Their effect on exotic plantations, indigenous forest and on some timber buildings. The Empire Forestry Journal 24:192-195.

Kormanik, P. 1990. Liquadambar styraciflua, sweetgum. In: Silvics of North America: 2. Hardwoods. Burns, R.M., and B.H. Honkala, Tech. Coords. http://www.na.fs.fed.us/ 
spfo/pubs/silvics_manual/table_of_contents.htm (accessed 3/8/06) Agriculture Handbook 654 Vol. 2 of the USDA Forest Service, Washington, DC. 877 pp.

Niklas, K.J. 1999. Changes in the factor of safety within the superstructure of a dicot tree. American Journal of Botany 86:688-696.

Peterson, C.J., and S.T.A. Pickett. 1991. Treefall and resprouting following catastrophic windthrow in an oldgrowth hemlock-hardwoods forest. Forest ecology and management 42:205-217.

Putz, F.E., P.D. Coley, K. Lu, A. Montalvo, and A. Aiello. 1983. Uprooting and snapping of trees: Structural determinants and ecological consequences. Canadian Journal of Forest Research 13:1011-1020.

Reyes, G., S. Brown, J. Chapman, and A.E. Lugo. 1992. Wood densities of tropical tree species. Gen. Tech. Rep. SO-88 of the USDA Forest Service Southern Forest Experiment Station. New Orleans, LA. 15 pp.

Skatter, S., and B. Kucera. 2000. Tree breakage from torsional wind loading due to crown asymmetry. Forest Ecology and Management 135:97-103.

Swain, K.M. 1979. Minimizing timber damage from hurricanes. Southern Lumberman 239:107-109.

Tanner, E.V.J., V. Kapos, and J.R. Healey. 1991. Hurricane effects on forest ecosystems in the Caribbean. Biotropica 23:513-521.

Touliatos, P., and E. Roth. 1971. Hurricanes and trees: Ten lessons from Camille. Journal of Forestry 69:285-289.

Van Hooser, D.D., and A. Hedlund. 1969. Timber damaged by Hurricane Camille in Mississippi. Research Note SO96 of the USDA Forest Service Southern Forest Experiment Station, New Orleans, LA. 5 pp.

Walker, L.R. 1991. Tree damage and recovery from hurricane Hugo in Luquillo Experimental Forest, Puerto Rico. Biotropica (Part A. Special Issue: Ecosystem, Plant, and Animal Responses to Hurricanes in the Caribbean) 23: 379-385.

Webb, S.L. 1989. Contrasting windstorm consequences in two forests, Itasca State Park, Minnesota. Ecology 70: 1167-1180.

Zimmerman, J.K., E.M. Everham III, R.B. Waide, D.J. Lodge, C.M. Taylor, and N.V.L. Brokaw. 1994. Responses of tree species to hurricane winds in a subtropical wet forest in Puerto Rico: Implications for tropical tree life histories. Journal of Ecology 82:911-922.

Mary L. Duryea (corresponding author)

Professor and Associate Dean

Institute of Food and Agricultural Sciences

University of Florida

P.O. Box 110200

Gainesville, FL 32611-0200, U.S.

mlduryea@ufl.edu
Eliana Kampf

Urban Forest Research Associate

School of Forest Resources and Conservation

University of Florida

P.O. Box 110831

Gainesville, FL 32611-0831, U.S.

Ramon C. Littell

Professor

Department of Statistics

University of Florida

P.O. Box 110339

Gainesville, FL 32611-0339, U.S.

Résumé. Plusieurs ouragans ont frappé la Floride en 2004 et 2005, causant de vastes dommages aux zones urbaines et rurales. Nous avons mesuré les impacts de cinq de ces ouragans sur la forêt urbaine et combinés ces résultats avec quatre autres ouragans afin de présenter une évaluation de la résistance au vent pour les espèces d'arbres de la plaine côtière du Sud-est des États-Unis. La perte au sein de la forêt urbaine était largement corrélée avec la vitesse du vent. Les espèces d'arbres qui ont démontré la plus grande résistance à survivre face aux vents ont été le Quercus geminata, le Ilex opaca, le Magnolia grandiflora, le Quercus virginiana, le Myrica cerifera, le Liquidambar styraciflua, le Lagerstroemia indica, le Cornus florida et le Sabal palmetto. Dans une comparaison statistique du taux de survie après quatre ouragans côtiers entre le $Q$. geminata, le $Q$. virginiana et le $Q$. laurifolia, le $Q$. laurifolia a eu le plus faible taux de survie par rapport aux deux autres. Parmi toutes les espèces, les arbres de grande taille ont perdu plus de branches que les arbres de moyenne ou petite taille. La perte en feuilles a été en relation positive avec le taux de survie - la perte de feuilles durant l'ouragan a résulté en un plus grand taux de survie. Les arbres poussant en groupes ou en bosquets ont eu un taux de survie plus élevé que ceux poussant individuellement. Les espèces d'arbres avec une densité en bois plus élevée ont eu un meilleur taux de survie. Les espèces d'arbres classées comme ayant une cime plus dense ont perdu plus de branches que celles avec une cime plus faible ou clairsemée; cependant, contrairement à ce qui est affirmé dans la littérature, les espèces avec une cime plus dense ont mieux survécu. Un inventaire fait par des arboriculteurs, des scientifiques et des forestiers urbains a permis de classifier les espèces selon leur résistance au vent. En utilisant les résultats provenant de nos mesures des ouragans et en les incorporant avec ceux provenant de l'inventaire et les données de la littérature scientifique, nous avons développé une liste de résistance relative au vent pour les espèces de la plaine côtière du Sudest. Ces listes devraient être utilisées avec précaution, et ce du fait qu'aucune espèce ou aucun arbre n'est totalement insensible au vent. De plus, d'autres aspects locaux, tels le sol, les pratiques culturales, l'âge et la santé de l'arbre ainsi que les autres aspects de la forêt urbaine doivent être pris en compte.

Zusammenfassung. 2004 und 2005 wurde Florida von mehreren Stürmen heimgesucht, die in weiten Landesteilen große Zerstörung anrichteten. Wir haben die Auswirkungen von fünf dieser Stürme auf die urbanen Wälder gemessen und diese Ergebnisse mit vier 
anderen Stürmen verbunden, um eine Untersuchung der Windresistenz von Baumarten der amerikanischen Südostküste zu präsentieren. Der Verlust an urbanen Wäldern wurde positiv korreliert mit der Windgeschwindigkeit. Die Bäume mit der größten Überlebensrate waren: Quercus geminata, Ilex opaca, Magnolia grandiflora, Quercus virginiana, Myrica cerifera, Liquidambar styraciflua, Lagerstroemia indica, Cornus florida und Sabal palmetto. In einem statistischen Vergleich von $Q$. geminata, $Q$. virginiana und $Q$. laurifolia nach vier heftigen Wirbelstürmen zeigte die Lorbeereiche eine deutlich niedrigere Überlebensrate als die beiden anderen Eichen. Von allen Arten verloren im Vergleich die größeren Bäume mehr Äste als die mittleren und kleineren Baumarten. Der Blattverlust hatte eine positive Korrelation mit der Überlebensrate: ein Verlust der Blätter während des Sturmes verhieß größeres Überleben nach dem Sturm. Bäume, die in kleineren oder größeren Gruppen wuchsen, hatten eine größere Überlebenschance als Einzelbäume. Baumarten mit naturgemäß dichten Kronen verloren mehr Äste als Baumarten mit mittleren oder offenen Kronenhabitus. Dennoch, im Gegensatz zur Literatur hatten dichtbekronte Bäume eine höhere Überlebensrate. In einer Umfrage unter Arboristen, Wissenschaftlern und Forstleuten wurden Baumarten auf ihre Windresistenz bewertet. Mit den Ergebnissen unserer Sturmmessungen, den Ergebnissen der Umfrage und der wissenschaftlichen Literatur entwickelten wir eine Liste von relativem Windwiderstand für Baumarten entlang der Südostküste Amerikas. Diese Listen könne unter dem Vorbehalt verwendet werden, dass keine Art und kein Baum komplett windresistent ist. Zusätzliche Standortbedingungen, wie Boden, Kulturart, Baumalter und Gesundheit sowie andere urbane Forstverhältnisse müssen mit einbezogen werden.

Resumen. Varios huracanes golpearon Florida en 2004 y 2005 causando extensos daños a las áreas rurales y urbanas. Se midieron los impactos de cinco de estos huracanes en el bosque urbano y se combinaron estos resultados con otros cuatro huracanes para pre- sentar una evaluación de la resistencia del viento para especies de árboles de las planicies costeras del sureste del los EU. La pérdida de bosque urbano estuvo correlacionada positivamente con la velocidad del viento. Las especies de árboles que demostraron la más alta supervivencia en los vientos fueron los encinos (Quercus geminata y Quercus virginiana), holly americano (Ilex opaca), magnolia (Magnolia grandiflora), mirica de cera (Myrica cerifera), liquidámbar (Liquidambar styraciflua), astronómica (Lagerstroemia indica), cornus (Cornus florida) y palma sabal (Sabal palmetto). En comparación estadística de los encinos y el encino laurel (Quercus laurifolia), después de cuatro fuertes huracanes, el encino laurel tuvo una menor supervivencia, significativamente más pobre, que los dos encinos evaluados. Entre todas las especies, los árboles grandes perdieron más ramas que los medianos y pequeños. La pérdida de hojas tuvo una relación positiva con la supervivencia - pérdida de hojas durante el huracán, significativamente con más alta supervivencia. Los árboles creciendo en grupos tuvieron más alta supervivencia que los árboles aislados. Las especies de árboles con densidad de madera más alta tuvieron mayor supervivencia. Las especies de árboles en categorías de densidades de copa mayores perdieron más ramas que aquellos con copas moderadas o abiertas; sin embargo, contrariamente a la literatura, las especies de copas densas supervivieron mejor. Una encuesta de arboristas, científicos y dasónomos urbanos clasificaron las especies por su resistencia al viento. Empleando los resultados de este estudio e incorporándolos a los de la encuesta y la literatura científica, se han desarrollado listas de resistencia relativa al viento para especies de árboles en las planicies costeras del sureste. Estas listas deberían ser usadas con precaución, con el conocimiento de que no todas las especies y no todos los árboles están completamente protegidos contra los vientos. Además de consideraciones locales tales como suelos, prácticas culturales, edad del árbol y salud, otras condiciones del bosque urbano necesitan ser tomadas en cuenta. 